\title{
In Memoriam: John A. Milner
}

Jeffrey B. Blumberg

Correspondence to:

(C) Springer - CEC Editore 2014

John A. Milner, $\mathrm{PhD}$, a dedicated member of the Nutrafoods editorial board, passed away at the age of 66 on 31 December 2013. He was internationally renowned for his work in human nutrition and cancer prevention. His career included leadership positions at the University of Illinois, Pennsylvania State University and National Cancer Institute, and most recently, he served as the director of the United States Department of Agriculture Beltsville Human Nutrition Research Center. Dr. Milner was elected as a fellow of the American Association for the Advancement of Science, Insticomplextute of Food Technologists and American Society for Nutrition and as an honorary member of the Academy of Nutrition and Dietetics. He was an early contributor and global expert on the concepts of functional foods and nutrigenomics, but was known widely for communicating complex technical ideas along with homespun humour. He is survived by his two children with Mary Frances Picciano, another distinguished nutrition scientist, who died in 2010, and is remembered by a legion of loyal colleagues. 